\title{
Environmental Management and Development Strategy of Cross-border River Water Resources
}

\author{
Zhen Zhen* \\ Yunnan University of Business Management, Kunming 650106, Yunnan, China
}

\begin{abstract}
International Rivers pass through more than two countries, which makes it difficult to manage international rivers. Nowadays, the integration of world economic development determines the increasingly close cooperation between countries. The international river has become a hot area of economic development. How to rationally develop and utilize the international river and make it healthy and sustainable development is an important problem facing all countries. China is rich in cross-border river water resources. With the increasingly obvious economic status of cross-border river water resources, how to use cross-border river is an urgent problem. Combined with the distribution characteristics of cross-border rivers in China, this paper discusses the strategic significance of cross-border river development and utilization for national development, combs the current situation of cross-border river development and utilization, and puts forward corresponding measures for cross-border river development strategy, which has reference value for solving the problems caused by cross-border river development.
\end{abstract}

\section{Introduction}

The river system is a whole unit composed of many crisscross river systems. The geographical environment of the river basin affects the water cycle of the river system. The international river is a river formed by natural water, and the basin area is more than two countries. China has the third largest number of international rivers in the world. Different sections of international rivers are located in different countries and regions, different countries are located in different geographical conditions, and different countries have different degrees of development and utilization of river basins, so it is difficult to manage international rivers in cross-border areas. Nowadays, the integration of world economic development determines that the cooperation between countries is getting closer and closer, and the cooperation between different countries is becoming more and more urgent. With the economic development of various countries, cross-border rivers have become hot areas of economic development. How to protect the water resources of cross-border rivers is an important issue for all countries. The Belt and the Road is a geopolitical strategy to realize the great rejuvenation of the Chinese nation. Solving the problem of cross boundary rivers in China will help to implement the strategy of Fortune Community.

\section{Significance of the development and management of cross-border river water resources}

Water resource is the basic condition to maintain the operation of life system. The renewable capacity of water resources is affected by many factors. The natural renewable capacity depends on the natural cycle of water resources. The development and utilization of water resources beyond the renewable capacity will extend its regeneration cycle [1]. The capacity of artificial regeneration depends on the development of social economy. $97.5 \%$ of water resources on the Earth are sea water, and most of the fresh water is polar glaciers and deep groundwater. After the 1950s, the population increased rapidly. With the rapid increase of human demand for water resources, water pollution is becoming increasingly serious, which reduces the quality of water resources and leads to the loss of basic functions of water resources.

The problem of water will restrict the development of global economy in the 21 st century. At present, about 3 billion people in the world are lack of water and sanitation facilities. The water resource crisis brings about the deterioration of ecosystem and threatens the living environment of human beings. The crisis of water resources limits the sustainable development of all countries. At present, the distribution of fresh water resources in the world is uneven, and the relationship between human and water is not harmonious, which makes the shortage of water resources increasingly and aggravates the conflicts between regions. The development and utilization of international cross-border rivers have been widely valued by all countries. In recent years, the development and utilization of cross-border river water resources in the Nile River and other basins have caused national conflicts. How to reasonably

\footnotetext{
*Corresponding author: 472958384@qq.com
} 
allocate international cross-border river water resources, how to effectively coordinate and solve conflicts, and how to manage and develop cross-border river water resources through international cooperation have become urgent problems [2]. At present, European countries have some experience in the fields of allocating international river water resources and coordinating cross-border River conflicts, while the related research in China is relatively weak. It is particularly important for China to participate in international river regional cooperation and safeguard its own interests in water resources.

There are 42 cross-border rivers in China, which are mainly distributed in the northwest. The border line of water area is more than $5000 \mathrm{~km}$ long. The southwest area is mainly connected watercourses. The cross-border rivers involve 19 basin countries. The economic and social background of rivers in each area is quite different, which affects the stability of surrounding countries. In order to alleviate the shortage of water resources, China has carried out moderate development of cross-border rivers, but the overall degree of development is low, and the southwest region is the region with the lowest social and economic development. The development and utilization of cross-border rivers affect the development of the western region. Actively promoting the development of cross-border river water resources is the requirement of building a well-off society. Cross border river development is of great strategic significance to promote the security and stability of the basin.

The belt and the Road will promote wide implement in the drainage cooperation projects, and it will also help to solve the contradictions in cross border development. Taking advantage of China's water resources technology is conducive to upgrading water conservancy infrastructure construction[3]. We can gradually promote interconnection of infrastructure, focus on promoting economic cooperation and seek common development of basin countries. China's cross-border rivers have a large amount of outbound water. Through the active development of cross-border river resources, we can reduce the dependence on oil, provide strong energy reserves for China's development, and expand the space for China's economic development. Actively developing cross-border water resources plays an important role in maintaining the security of the western region. The Belt and the Road will open up new opportunities for the complementary advantages of the river basin and help to stabilize the external environment of the border area through the development of cross border water resources.

\section{Current situation of development and management of international cross-border river water resources}

At present, the distribution of fresh water resources in the world is quite different, and the demand for water resources in various countries is increasing day by day. The development and utilization of cross-border rivers are concerned by many countries. Conflicts often occur in the development and utilization of international river water resources in Jordan River Basin. After the Cold War, many new cooperation zones were carried out on the theme of the development of cross-border rivers. Under the global trend of international fair distribution, it is of great significance to avoid the conflict of international river water resources for promoting the sustainable development of all countries. There are many ways to solve the conflict of international river water resources, including legal means and political means. It is the most feasible way to develop and manage international rivers through international cooperation.

After the emergence of countries in the world, the natural attributes of rivers have changed, and they are divided into national inland rivers and international rivers. Cross-border rivers involve many fields such as politics and economy, and the development and management of cross-border rivers are more complex. Cross-border rivers are rivers whose natural components are located in different countries. There are a large number of international rivers and their distribution changes under certain conditions. The reasons for the change of the number of cross-border rivers include the change of political boundaries, which led to the change of national inland rivers into international rivers; the application of high-precision maps found the border lines that had not been found in the past, and the registration of international rivers was updated and improved in 1977 to increase the number of cross-border rivers[4]. According to the definition of cross-border River, it can be divided into boundary river and cross-border river. Cross-border rivers are rivers that cross national boundaries. For example, international rivers in Northwest and southwest China are cross-border rivers. Due to the different geographical location, different countries have different needs. Usually downstream countries pay attention to flood control and irrigation.

Table 1. Distribution of international rivers in the world

\begin{tabular}{|c|c|c|c|}
\hline District & $\begin{array}{c}\text { The number of } \\
\text { international rivers } \\
2003\end{array}$ & $\begin{array}{c}\text { The number of international rivers } \\
2018\end{array}$ & $\begin{array}{c}\text { Proportion of international } \\
\text { river basin area to land area } \%\end{array}$ \\
\hline Africa & 57 & 60 & 62 \\
\hline $\begin{array}{c}\text { North } \\
\text { America }\end{array}$ & 33 & 39 & 35 \\
\hline $\begin{array}{c}\text { South } \\
\text { America }\end{array}$ & 36 & 38 & 60 \\
\hline Asia & 40 & 53 & 39 \\
\hline Europe & 48 & 71 & 54 \\
\hline Total & 215 & 261 & 45.3 \\
\hline
\end{tabular}


At present, there are many problems in the management of international river water resources, including the increasing cross-border pollution, the low level of development and utilization of international river water resources, and the continuous conflict of cross-border river water resources. With the increase of population, human demand for water increases. The unbalanced distribution of rivers in time and space causes the shortage of water resources. And conflicts often occur due to the water demand of each country in the basin, biological invasion and other reasons. For example, the conflict between Ganges basin and Bangladesh and India is more prominent. The cross-border rivers are usually located in the border areas, and the development capacity is limited, which leads to the low utilization rate of water resources. At present, the utilization rate of most international rivers is low. With the development of cross-border rivers and urban, the problem of cross-border pollution is common. For example, the Kazakh government has negotiated with the Chinese Embassy in Kazakhstan, saying that the pollution of Yili River poses a threat to the ecological environment in its territory. Mongolia and other countries have made representations on the water quality of rivers in China. Due to dam construction, water environment changes, such as land salinization and other issues, aquatic biodiversity is affected. With the increase of irrigation water, the net flow into the Aral Sea decreased.

International conflict is a state of confrontation caused by the different interests of the actors in international relations. The causes of international conflicts include ethnic and religious conflicts and different social systems and etc. The contradiction of water resources utilization is one of the important reasons. The conflict of cross-border river water resources is an important part of international conflicts, which refers to the conflict of water resources utilization in order to protect the quantity and quality of domestic water use in the cross-border River Basin countries when there is no common recognized management institution. It is quite common for countries in conflict to settle their problems through negotiation. Driven by the interests of water resources development, powerful countries will launch wars. There are various types of international conflicts. The conflicts of cross-border river water resources have their own characteristics, which are reflected in the diversification of forms, the expansion of the scope of conflicts, and the coexistence of conflicts and cooperation. There are many reasons leading to the conflict of cross-border river water resources, including social and political factors. The main reasons include the shortage of water resources, the difference of development goals, and the geopolitical influence of cross-border rivers and etc.

\section{Problems in the development and management of cross-border rivers in China}

China's cross-border rivers are distributed in the western and northern regions, and the cross-border shared water resources are concentrated in the southwest. Southwest
China is the water tower of the Asian continent. The cross-border rivers include Nujiang River - Salween River and bakirati River - Ganges River and other rivers. There are many glaciers and snow mountains in the basin, with glacial water reserves of about 10 billion cubic meters, affecting the development and utilization of water resources in the West. China is rich in water resources in cross-border river basins. The large-scale development of cross-border rivers in Southwest China focuses on the hydropower development in the main stream of Lancang River, and Dachaoshan Hydropower Station has been built and etc. At present, there are some problems in the development and management of cross-border water resources in China, such as cross basin governance, external forces intervention and so on.

Most of the international river conflicts focus on water allocation. The international allocation of water resources in cross-border rivers is a common problem in river development and management, which is most likely to cause conflicts of interest among the countries in the river basin. China's cross-border rivers are related to the water allocation of cross-border rivers in Northwest China. Cross-border river water allocation is a complex issue involving the political and social development of relevant sovereign countries, which is of great significance to maintain the ecological security of the basin[5]. All countries enjoy equal rights on water use, but there are differences on how to allocate rights on water use. Upstream countries with superior geographical position in the river, can develop the river unilaterally, and the water use of source countries is not limited. Most of the cross-border rivers in Southwest China are located in the upstream of rivers, resulting in unbalanced water distribution. There are many contradictions and conflicts in the development and utilization of international rivers, such as the different geographical locations of the countries in the river basin, the contradictions caused by the diversity of demands for the development of international rivers, and the contradictions caused by local water conservancy projects. The essence is the contradiction in the exercise of sovereignty over international rivers.

\section{Countermeasures for development and management of cross-border river water resources}

The distribution of cross-border rivers in China is controlled by the surrounding geographical environment and concentrated in the northwest region. The development and utilization of cross-border river water resources is related to the national geopolitical and economic cooperation. There are different types of problems in different areas of cross-border River disputes in China. The cross-border rivers in Northwest China mainly involve water allocation disputes; the water quality of cross-border rivers in Northeast China is seriously polluted; the hydropower development of cross-border rivers in Southwest China leads to conflicts with downstream water allocation, which leads to ecological security conflicts and river basin governance 
problems. It is necessary to properly deal with the water resources and environmental management of cross-border rivers by establishing the overall planning and development model of the river basin.

International Water Law provides the basic starting point of negotiation and cooperation for basin countries, but it can not solve all the problems of cross-border river water resources. China should take the rational development of water resources as the overall goal, and actively develop cross-border river water resources. We should adhere to the principle of fair and reasonable utilization. The principle of fair and reasonable utilization is the core principle of international water law, which is conducive to safeguarding the right of water resources development and utilization in China. Harmless utilization is an important part of regional sustainable development, which is conducive to restricting the water use behavior in the basin and promoting the peace and stability of the basin. At present, the development and utilization of cross-border rivers in China is in the primary stage, mainly focusing on the traditional functions of rivers such as shipping. In the development of water resources, we should pay attention to the protection of ecosystem sustainability.

The development and utilization of cross-border river water energy in China started late. With the implementation of the Belt and the Road, the development of China's energy and technology is more and more important. It is necessary to strengthen the research on the trend of international water law and the possible international risks. The southwest cross-border River areas should be listed as priority areas, and the development timing and scale should be defined in the specific development plan. At present, China has not yet established a cross-border river management institution with neighboring River Basin countries, so we should improve the management mechanism to solve international disputes. It is required to build a negotiation mechanism for cross-border rivers, adhere to the basic principle of prevention first, aimed at cross-border River conflicts, and avoiding damage disputes. Reaching an agreement through negotiation solves the inevitable loss.

The development and utilization of cross-border river water resources need international cooperation, and make use of China's capital and technology advantages to make basin countries share the development and prosperity brought by water resources. At present, China is in the transition period of economic growth mode. We should start from establishing joint management mechanism with basin countries to realize the sustainable development and utilization of cross-border river water resources. Through strengthening joint research with basin countries, actively seek common views, and fully tap the potential of joint development. International river is an organic whole, which must be regarded as a special economic system. The river basin planning should be unified according to the rule of economy, nature and society, and the international river cooperative development planning should be formulated reasonably. Meet the water demand of coastal countries by signing agreements with basin countries. The scheme should realize protection in using.

\section{Conclusion}

The development and utilization of international rivers is a complex issue involving the interests of many countries, and all countries shoulder the unshirkable responsibility for the ecological protection of international rivers. Environmental pollution is often irreversible. Under the new situation, the problem of cross-border rivers has become increasingly prominent. To deal with the problem of cross-border rivers, we need to comprehensively consider various factors when accelerating the development and utilization of cross-border rivers, which is conducive to the realization of major strategic objectives. According to the principles of international water law, reasonable development and utilization of cross-border river water resources is conducive to maintaining regional stability. China should face the bottleneck problem in the development as a responsible power, and properly solve the conflict of water resources utilization in international rivers by strengthening communication and cooperation with basin countries.

\section{References}

1. Changzheng Zhang, Pinting Zhen. Strategy Selection and Factor Analysis of National Water Resources Utilization in Lancang Mekong Basin - A Case Study of the Game Between "Shawan, Laos and Modahan, Thailand"[J/OL]. Resources \& Industries:1-11[2021-01-26]. https://doi.org/10.13776/j.cnki.resourcesindustries.20 201125.007.

2. Chenjia Zhang. Study on Livelihood Capital Evaluation and Livelihood Sustainability of Farmers in Koshi River Basin[D]. (Chengdu Institute of Mountain Hazards and Environment, Ministry of Water Resources, Chinese Academy of Sciences), 2020.

3. Fang Li, Fengping $\mathrm{Wu}$, Liuxin Chen, Xia Xu. Hawk-dove Game Model of Transboundary Water Resources Conflict and Cooperation from an Asymmetric Perspective[J]. China Population, Resources and Environment, 2020,30(05):157-166.

4. Guiliang Tian, Xiaoning Li, Jining Liu. Path to Trans-region Water Resource Conflicts by Water Right Trading Viewing from Incomplete Contract[J]. Resources \& Industries, 2020,22(03):43-50.

5. Ye Han. India's Perception of and Strategy Options regarding Sino-India Transboundary Water Issues[J]. South Asian Studies, 2020(01):53-73+149-150. 